\title{
Democratic Governance
}


This page intentionally left blank 


\title{
Democratic Governance
}

\author{
Mark Bevir
}

P R I N C E T O N U N I E R S T Y PRES S

P R I N C E T O N A N D OXFOR D 
Copyright (9) 2010 by Princeton University Press

Requests for permission to reproduce material from this work should be sent to Permissions, Princeton University Press

Published by Princeton University Press, 41 William Street, Princeton, New Jersey 08540

In the United Kingdom: Princeton University Press, 6 Oxford Street, Woodstock, Oxfordshire OX20 1TW

All Rights Reserved

Library of Congress Cataloging-in-Publication Data

Bevir, Mark.

Democratic governance / Mark Bevir.

p. $\mathrm{cm}$.

Includes bibliographical references and index.

ISBN 978-0-691-14538-9 (hardcover : alk. paper)

ISBN 978-0-691-14539-6 (pbk. : alk. paper)

1. Democracy. 2. Public administration. 3. State, The. I. Title.

JC423.B428 $2010 \quad 321.8-\mathrm{dc} 22$

2009052058

British Library Cataloging-in-Publication Data is available

This book has been composed in Sabon

Printed on acid-free paper. $\infty$

press.princeton.edu

Printed in the United States of America

$\begin{array}{llllllllll}10 & 9 & 8 & 7 & 6 & 5 & 4 & 3 & 2 & 1\end{array}$ 
To Harry 
This page intentionally left blank 